\title{
Pseudogout: a rare cause of joint swelling during postoperative period
}

\author{
Kamal Kant Sahu, ${ }^{\circledR}$ Ajay Kumar Mishra, Dhinager Nandagopal
}

Department of Internal Medicine, Saint Vincent Hospital, 123 Summer Street, Worcester, MA, USA

\section{Correspondence to} Dr Kamal Kant Sahu, drkksahu85@gmail.com

Accepted 3 April 2019

\section{DESCRIPTION}

A 50-year-old man presented to the emergency department for left lower limb pain of one day duration. He recently underwent right sided total knee replacement (TKR) three weeks ago which was complicated by left lower limb deep venous thrombosis (DVT) requiring coumadin therapy. At presentation, the pain was severe enough to compromise his ambulation. The initial concern of the proximal progression of his DVT was considered less likely as review of his electronic medical records suggested that he was anticoagulated adequately with a target international normalised ratio being maintained between 2 to 3 . Examination revealed swelling, erythema over ankle joint which was extremely tender to touch (figure 1A). No swelling or tenderness was noted over calf muscles bilaterally. His vital signs suggested fever of $101^{\circ} \mathrm{F}$. X-ray of ankle joint suggested soft tissue swelling overlying the lateral malleolus (figure 1B). Joint aspiration showed dark yellow cloudy synovial fluid with leucocyte count of $30 \times 10^{9} / \mathrm{L}, 95 \%$ neutrophils and normal glucose levels. Microscopy showed an abundance of small rod-like rhomboid-shaped, weak positive birefringent crystals (figure 1C,D). Gram stain and fluid culture were negative confirming the diagnosis of pseudogout also known as calcium pyrophosphate dihydrate crystals deposition disease (CPPD). Potential secondary causes like hyperparathyroidism, haemochromatosis and electrolyte imbalances were ruled out. He was started on tablet colchicine $0.6 \mathrm{mg}$ two times per day with improvement in symptoms over the next 2 days.

Differential diagnosis of lower limb pain especially during postoperative period can be due to multiple reasons. Septic arthritis, deep venous thrombosis, venous stasis are the scenarios commonly encountered. There was an initial concern of progression of DVT in our patient as well which was ruled out by doppler study. Rare reports of CPPD flare following total knee replacement (TKR) have been reported in the past. ${ }^{1}$ George et al in their institutional study (2000-2016) reported 22 cases of post-implant pseudogout. $^{2}$ In any case, aspiration of the joint for synovial fluid analysis, microscopy, gram stain and culture is of utmost importance. Rare cases of coexistent pseudogout and septic arthritis have also been reported. ${ }^{3}$ This makes it very crucial for the treating physician to ensure that gram stain and culture from the synovial fluid are negative before labelling a case exclusively as CPPD . As also noted in our case, immobilisation following TKR predisposed to thrombosis for which he was treated with coumadin. In addition to the complexities associated with thrombosis, it is also essential to be aware of the warafin related side effects. $^{45}$

\section{Learning points}

- Calcium pyrophosphate dihydrate crystals deposition disease and septic arthritis can coexist in the same event making it mandatory to process the synovial sample diligently for both crystals and gram stain/cultures.

- Limb/joint pain during post procedure (eg, TKR) period must be evaluated thoroughly for deep venous thrombosis, gout, pseudogout and septic arthritis which can occur in alone or in combination.

Contributors KKS: paper writing; AKM: literature search; DN: review and editing.

Funding The authors have not declared a specific grant for this research from any funding agency in the public, commercial or not-for-profit sectors.

\section{Check for updates}

(C) BMJ Publishing Group Limited 2019. No commercial re-use. See rights and permissions. Published by BMJ.

To cite: Sahu KK, Mishra AK, Nandagopal D. BMJ Case Rep 2019;12:e230089. doi:10.1136/bcr-2019230089

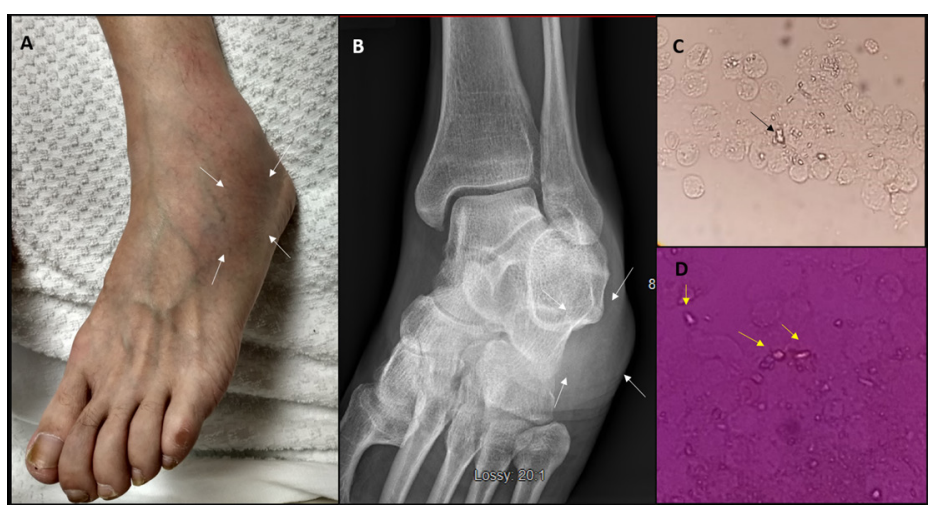

Figure 1 (A) Clinical image showing swelling of the left ankle. (B) X-ray ankle joint showing soft tissue swelling. (C and D) Direct microscopy showing rhomboid-shaped crystals confirmed by polarised light. 
Images in...

Competing interests None declared.

Patient consent for publication Obtained.

Provenance and peer review Not commissioned; externally peer reviewed.

\section{REFERENCES}

1 Argyropoulos M, lyengar KP, Suraliwala KH. First presentation of acute pseudogout following total knee replacement. J Orthop Case Rep 2018;8:32-4.
2 George MP, Ernste FC, Tande A, et al. Clinical presentation, management, and prognosis of pseudogout in joint arthroplasty: a retrospective cohort study. J Bone Jt Infect 2019;4:20-6.

3 Colaco C, Dotel R. Coexisting polyarticular septic arthritis, gout and pseudogout. BMJ Case Rep 2018;2018:bcr-2018-226810.

4 Sahu KK, Varma SC. Warfarin induced skin necrosis. Indian J Med Res 2016;143:528-37

5 Sahu KK, Varma SC. Cortical vein thrombosis in a case of idiopathic thrombocytopenic purpura. Platelets 2015;26:374-5.

Copyright 2019 BMJ Publishing Group. All rights reserved. For permission to reuse any of this content visit

https://www.bmj.com/company/products-services/rights-and-licensing/permissions/

BMJ Case Report Fellows may re-use this article for personal use and teaching without any further permission.

Become a Fellow of BMJ Case Reports today and you can:

- Submit as many cases as you like

- Enjoy fast sympathetic peer review and rapid publication of accepted articles

- Access all the published articles

Re-use any of the published material for personal use and teaching without further permission

For information on Institutional Fellowships contact consortiasales@bmjgroup.com

Visit casereports.bmi.com for more articles like this and to become a Fellow 